\title{
Teaching Ethics Using Tax Evasion Survey Data as a Case Study
}

\author{
Robert W. McGee \\ Barry University, USA
}

\begin{abstract}
This paper briefly discusses the three views that have emerged over the centuries on the ethics of tax evasion, then summarizes the results of several opinion surveys that were conducted on the topic. The paper concludes with a discussion of how these study results may be used in the classroom.
\end{abstract}

Most research on the topic of tax evasion has been from the perspective of economics or public finance. Very little research on this issue has been done from an ethical perspective. One of the most comprehensive twentieth century studies on the topic from an ethical perspective was a doctoral thesis written by Martin Crowe (1944). He examined and summarized 500 years of theological and philosophical literature on the topic, some of which was in Latin. A later work by McGee (1998) included the views of more than twenty religious and secular scholars on the topic. Torgler (2003) did a major study of tax evasion from both an ethical and public finance perspective.

An examination of the literature reveals that three main views on the ethics of tax evasion have emerged over the centuries. One view, which may be called the absolutist position, holds that tax evasion is always, or almost always unethical. Those who hold this view believe that individuals have a duty to the state, to God or to some subset of the population, or society. Some Jewish (Cohn, 1998; Tamari, 1998), Christian (Smith \& Kimball, 1998) and Baha’i (DeMoville, 1998) scholars hold this view.

Another view, what may be labeled the anarchist position, holds that there is never anything unethical about evading taxes because all governments are illegitimate, mere thieves that confiscate property. The anarchist literature does not deal with tax evasion specifically. The more usual approach is to discuss the relationship of the individual to the state. The work of Spooner (1870) provides one of the best examples of this approach, although at least one anarchist has applied anarchist theory to taxation from the public finance perspective (Block, 1989; 1993).

The third view, which is the predominant view in the literature (Crowe, 1944), sees tax evasion as something that is ethical in some cases and unethical in others. Gronbacher (1998) discusses the Catholic viewpoint. Pennock (1998) discusses tax evasion in connection with war resistance. Schansberg (1998) discusses the issue from the perspective of Biblical Christianity.

\section{Method}

The author constructed a survey instrument to learn what various segments of populations in different cultures thought about the ethics of tax evasion. The survey incorporated all the major issues that Crowe (1944) had identified in his research. The survey consisted of a series of statements. Participants were asked to place a number from one to seven in the space provided to indicate the extent of their agreement with each statement $(1=$ strong agreement; 7 = strong disagreement).

An English language version of the survey was distributed to international business professors (McGee, 2005b) and philosophy professors (McGee, 2006). A Spanish version was distributed to Guatemalan business and law students (McGee \& Lingle, 2005). A Romanian McGee, R. W. (2006). Teaching ethics using tax evasion survey data as a case study. In M. S. Plakhotnik \& S. M. Nielsen (Eds.), Proceedings of the Fifth Annual College of Education Research Conference: Urban and International Education Section (pp. 70-75). Miami: Florida International University. http://coeweb.fiu.edu/research_conference/. 
language version was distributed to Romanian business students (McGee, 2005a). A Chinese language version was distributed to business students in Beijing (McGee \& An, 2006) and Hong Kong (McGee \& Ho, 2006). The Chinese version contained 15 statements. The other versions had 18 statements.

\section{Results}

The results, which are summarized in Table 1, revealed several things. Tax evasion is more acceptable in some cultures than others. Some arguments justifying tax evasion are stronger than others, but different cultures rank the arguments differently. What may be the strongest argument for or against tax evasion in one culture may have a significantly different ranking in another culture.

Comparing the scores of the Beijing and Hong Kong surveys was especially revealing. Although both groups of respondents were Chinese, and thus share a common culture, the scores for the Hong Kong group were significantly higher than the scores of the Beijing group for almost all 15 statements, indicating that people in Hong Kong are much more opposed to tax evasion than are people from Beijing. In some cases the scores varied by more than one point.

This difference could be explained by the fact that Beijing has been part of communist China since 1949, and that people who live under communist regimes tend to view their government more negatively than do people who live in a market economy. Hong Kong, although now a part of communist China, continues to maintain a market economy that has a strong rule of law and protection of property rights.

The country with scores closest to those of Beijing is Romania, which is a former communist country. The fact that 12 of the 15 scores that could be compared (the Beijing survey contained 15 statements whereas the Romanian survey had 18) were higher for Romania than for Beijing indicates that Romanians are generally more opposed to tax evasion than are the Chinese. Perhaps the Romanian scores would have been lower if an older group would have been surveyed. Most of the individuals who participated in the Romanian survey were too young to remember the communist regime, which lost its grip on Romania in 1989.

The scores for the Guatemalan and Hong Kong surveys were generally close, often no more than three-tenths of a point apart. The Guatemalan scores were higher than the Hong Kong scores for 8 of the 15 statements, whereas the Hong Kong scores were higher than the Guatemalan scores for only 5 of 15 statements, indicating that the Guatemalan sample was slightly more opposed to tax evasion than was the Hong Kong group. This small gap may diverge as Hong Kong becomes more communist and Guatemala becomes more market oriented. However, this might not happen, since mainland China, which exercises an increasing amount of influence over Hong Kong, is expanding its market sector.

Table 2 shows the frequency with which each group had the highest score. International business professors are far in first place, with 15 first place finishes, indicating that they were more opposed to tax evasion than any other group for 15 of the 18 statements. Second place went to philosophy professors, with 4 first place finishes. Guatemala scored 2 and Romania scored 1. China and Hong Kong both scored 0.

Table 3 shows the frequency with which each group had the lowest score, meaning that tax evasion was most acceptable. China was the clear winner with eleven (11) first place finishes, followed by Romania with 3. Philosophy professors scored 2 and international business professors and Hong Kong scored one (1). Guatemala had 0 first place finishes.

The philosophy professors and international business professors earned their scores from the three human rights statements that were included in the survey (S 16-18), which means these 
two groups found tax evasion to be most ethical in cases where the government was violating the rights of the citizenry. These were the three statements that were omitted from the Beijing and Hong Kong surveys.

\section{Uses for this Information}

Aside from the usual scholarly academic uses for the information contained in this paper, teachers may use the survey instrument as the launching point for a discussion of ethics, political science, philosophy, economics or public finance. Professors of international business could use it to show that different cultures have different viewpoints about tax evasion. Political science and philosophy professors could use it to start a discussion about the relationship of the individual to the state and the responsibilities that individuals have to their government and their fellow citizens. Economics and public finance professors could use it as the starting point for a discussion of taxation.

The discussion might begin by distributing the survey to the class and asking them to fill it out as a class exercise and to hold onto it rather than hand it in. After they complete the survey, Table 1 could be distributed to the class so they can see how their answers compare to those of other cultures. After they receive Table 1, or perhaps before they receive it, the teacher might initiate a discussion about some of the statements contained in the survey instrument.

Readers who want to learn more about these surveys, as well as other similar surveys that were not mentioned in this brief paper, can find the full papers posted on the Social Science Research Network website. The full papers contain a much more detailed literature review and make a number of comparisons that cannot be discussed here due to space constraints.

\section{References}

Block, W. (1989). The justification of taxation in the public finance literature: A critique. Journal of Public Finance and Public Choice, 3, 141-158.

Block, W. (1993). Public finance texts cannot justify government taxation: A critique. Canadian Public Administration/Administration Publique du Canada, 36(2), 225-262. (Reprinted in The ethics of tax evasion, pp. 36-88, by R.W. McGee, Ed., 1998, Dumont, NJ: Dumont Institute).

Cohn, G. (1998). The Jewish view on paying taxes. Journal of Accounting, Ethics \& Public Policy, 1(2), 109-120. (Reprinted in The ethics of tax evasion, pp. 180-189, by R.W. McGee, Ed., 1998, Dumont, NJ: Dumont Institute)

Crowe, M. T. (1944). The Moral obligation of paying just taxes. The Catholic University of America Studies in Sacred Theology No. 84.

DeMoville, W. (1998). The ethics of tax evasion: A Baha'i perspective. Journal of Accounting, Ethics \& Public Policy, 1(3), 356-368. (Reprinted in The ethics of tax evasion, pp. 230240, by R.W. McGee, Ed., 1998, Dumont, NJ: Dumont Institute)

Gronbacher, G. M. A. (1998). Taxation: Catholic Social Thought and Classical Liberalism. Journal of Accounting, Ethics \& Public Policy, 1(1), 91-100. (Reprinted in The ethics of tax evasion, pp. 158-167, by R.W. McGee, Ed., 1998, Dumont, NJ: Dumont Institute)

McGee, R. W. (Ed.). (1998). The ethics of tax evasion. Dumont, NJ: The Dumont Institute for Public Policy Research.

McGee, R.W. (2005a). The ethics of tax evasion: A survey of Romanian business students and faculty. Andreas School of Business Working Paper Series, Barry University, Miami Shores, FL, USA. September. (Reprinted in Accounting and financial system reform in Eastern Europe and Asia, pp. 299-334, by. R.W. McGee \& G.G. Preobragenskaya, New York: Springer, 2006) 
McGee, R.W. (2005b, October). The ethics of tax evasion: A survey of international business academics. Paper presented at the $60^{\text {th }}$ International Atlantic Economic Society Conference, New York.

McGee, R. W. \& Lingle, C. (2005, October). The ethics of tax evasion: A survey of Guatemalan opinion. Paper presented at the $60^{\text {th }}$ International Atlantic Economic Society Conference, New York.

McGee, R. W. (2006, January). The ethics of tax evasion: A survey of philosophy professors. Andreas School of Business Working Paper Series, Barry University, Miami Shores, FL.

McGee, R. W. \& An, Y. (2006, January). The ethics of tax evasion: A survey of Chinese business and economics students. Paper presented at International Academy of Business and Public Administration Disciplines, Orlando, Florida.

McGee, R. W., \& Ho, S. M. (2006, January). The ethics of tax evasion: A survey of accounting, business and economics students in Hong Kong. Paper presented at International Academy of Business and Public Administration Disciplines, Orlando, Florida.

Pennock, R. T. (1998). Death and taxes: On the justice of conscientious war tax resistance. Journal of Accounting, Ethics \& Public Policy, 1(1), 58-76. (Reprinted in The ethics of tax evasion, pp. 124-142, by R.W. McGee, Ed., 1998, Dumont, NJ: Dumont Institute)

Schansberg, D. E. (1998). The ethics of tax evasion within Biblical Christianity: Are there limits to 'Rendering Unto Caesar'? Journal of Accounting, Ethics \& Public Policy, 1(1), 77-90. (Reprinted in The ethics of tax evasion, pp. 144-157, by R.W. McGee, Ed., 1998, Dumont, NJ: Dumont Institute)

Smith, S. R., \& Kimball, K. C. (1998). Tax evasion and ethics: A perspective from members of the Church of Jesus Christ of Latter-Day Saints. Journal of Accounting, Ethics \& Public Policy, 1(3), 337-348. (Reprinted in The ethics of tax evasion, pp. 220-229, by R.W. McGee, Ed., 1998, Dumont, NJ: Dumont Institute)

Social Science Research Network. WWW.SSRN.COM.

Spooner, L. (1870). No treason: The constitution of no authority, originally self-published by Spooner in Boston in 1870, reprinted by Rampart College in 1965, 1966 and 1971, and by Ralph Myles Publisher, Inc., Colorado Springs, Colorado in 1973.

Tamari, M. (1998). Ethical Issues in Tax Evasion: A Jewish Perspective. Journal of Accounting, Ethics \& Public Policy, 1(2), 121-132. (Reprinted in The ethics of tax evasion, pp. 168178, by R.W. McGee, Ed., 1998, Dumont, NJ: Dumont Institute)

Torgler, B. (2003). Tax morale: Theory and empirical analysis of tax compliance. Unpublished doctoral dissertation, Universität Basel.

Table 1

Scores and Rankings

\begin{tabular}{llllllll}
$\begin{array}{l}\text { Stmt. } \\
\#\end{array}$ & Statement & Rom. & Guat. & China & $\begin{array}{l}\text { Hong } \\
\text { Kong }\end{array}$ & $\begin{array}{l}\text { I.B. } \\
\text { Profs }\end{array}$ & Phil. \\
\hline 1 & Tax evasion is ethical if tax rates are & 4.17 & 5.2 & 4.0 & 5.3 & 5.76 & 5.18 \\
& $\begin{array}{l}\text { too high. } \\
2\end{array}$ & $(4)$ & $(10)$ & $(6)$ & $(8)$ & $(10)$ & $(9)$ \\
& Tax evasion is ethical even if tax rates & 5.00 & 6.3 & 4.7 & 6.0 & 6.23 & 6.10 \\
& are not too high. & $(15)$ & $(16)$ & $(8)$ & $(9)$ & $(11)$ & $(12)$ \\
3 & Tax evasion is ethical if the tax system & 3.87 & 4.5 & 3.4 & 4.5 & 5.03 & 4.59 \\
& is unfair. & $(1)$ & $(5)$ & $(3)$ & $(5)$ & $(5)$ & $(5)$
\end{tabular}




\begin{tabular}{|c|c|c|c|c|c|c|c|}
\hline 4 & $\begin{array}{l}\text { Tax evasion is ethical if a large portion } \\
\text { of the money collected is wasted. }\end{array}$ & $\begin{array}{l}4.38 \\
(7)\end{array}$ & $\begin{array}{l}4.4 \\
(4)\end{array}$ & $\begin{array}{l}3.1 \\
(1)\end{array}$ & $\begin{array}{l}4.2 \\
(3)\end{array}$ & $\begin{array}{l}5.13 \\
(7)\end{array}$ & $\begin{array}{l}5.37 \\
(10)\end{array}$ \\
\hline 5 & $\begin{array}{l}\text { Tax evasion is ethical even if most of } \\
\text { the money collected is spent wisely. }\end{array}$ & $\begin{array}{l}4.80 \\
(12)\end{array}$ & $\begin{array}{l}6.3 \\
(16)\end{array}$ & $\begin{array}{l}5.3 \\
(15)\end{array}$ & $\begin{array}{l}4.4 \\
(4)\end{array}$ & $\begin{array}{l}6.49 \\
(17)\end{array}$ & $\begin{array}{l}6.23 \\
(16)\end{array}$ \\
\hline 6 & $\begin{array}{l}\text { Tax evasion is ethical if a large portion } \\
\text { of the money collected is spent on } \\
\text { projects that I morally disapprove of. }\end{array}$ & $\begin{array}{l}4.69 \\
(10)\end{array}$ & $\begin{array}{l}4.8 \\
(8)\end{array}$ & $\begin{array}{l}4.3 \\
(7)\end{array}$ & $\begin{array}{l}4.7 \\
(6)\end{array}$ & $\begin{array}{l}5.25 \\
(8)\end{array}$ & $\begin{array}{l}5.15 \\
(8)\end{array}$ \\
\hline 7 & $\begin{array}{l}\text { Tax evasion is ethical even if a large } \\
\text { portion of the money collected is spent } \\
\text { on worthy projects. }\end{array}$ & $\begin{array}{l}4.72 \\
(11)\end{array}$ & $\begin{array}{l}5.8 \\
(11)\end{array}$ & $\begin{array}{l}5.2 \\
(13)\end{array}$ & $\begin{array}{l}6.4 \\
(14)\end{array}$ & $\begin{array}{l}6.43 \\
(15)\end{array}$ & $\begin{array}{l}6.16 \\
(13)\end{array}$ \\
\hline 8 & $\begin{array}{l}\text { Tax evasion is ethical if a large portion } \\
\text { of the money collected is spent on } \\
\text { projects that do not benefit me. }\end{array}$ & $\begin{array}{l}4.95 \\
(14)\end{array}$ & $\begin{array}{l}6.0 \\
(12)\end{array}$ & $\begin{array}{l}4.9 \\
(10)\end{array}$ & $\begin{array}{l}6.2 \\
(13)\end{array}$ & $\begin{array}{l}6.34 \\
(14)\end{array}$ & $\begin{array}{l}6.19 \\
(14)\end{array}$ \\
\hline 9 & $\begin{array}{l}\text { Tax evasion is ethical even if a large } \\
\text { portion of the money collected is spent } \\
\text { on projects that do benefit me. }\end{array}$ & $\begin{array}{l}4.86 \\
(13)\end{array}$ & $\begin{array}{l}6.3 \\
(16)\end{array}$ & $\begin{array}{l}5.2 \\
(13)\end{array}$ & $\begin{array}{l}6.5 \\
(15)\end{array}$ & $\begin{array}{l}6.52 \\
(18)\end{array}$ & $\begin{array}{l}6.22 \\
(15)\end{array}$ \\
\hline 10 & $\begin{array}{l}\text { Tax evasion is ethical if everyone is } \\
\text { doing it. }\end{array}$ & $\begin{array}{l}5.24 \\
(18)\end{array}$ & $\begin{array}{l}6.2 \\
(14)\end{array}$ & $\begin{array}{l}4.7 \\
(8)\end{array}$ & $\begin{array}{l}6.0 \\
(9)\end{array}$ & $\begin{array}{l}6.28 \\
(12)\end{array}$ & $\begin{array}{l}5.72 \\
(11)\end{array}$ \\
\hline 11 & $\begin{array}{l}\text { Tax evasion is ethical if a significant } \\
\text { portion of the money collected winds } \\
\text { up in the pockets of corrupt politicians } \\
\text { or their families and friends. }\end{array}$ & $\begin{array}{l}4.18 \\
(5)\end{array}$ & $\begin{array}{l}3.7 \\
(1)\end{array}$ & $\begin{array}{l}3.2 \\
(2)\end{array}$ & $\begin{array}{l}3.7 \\
(1)\end{array}$ & $\begin{array}{l}4.35 \\
(3)\end{array}$ & $\begin{array}{l}4.53 \\
(4)\end{array}$ \\
\hline 12 & $\begin{array}{l}\text { Tax evasion is ethical if the probability } \\
\text { of getting caught is low. }\end{array}$ & $\begin{array}{l}5.16 \\
(17)\end{array}$ & $\begin{array}{l}6.2 \\
(14)\end{array}$ & $\begin{array}{l}5.1 \\
(11)\end{array}$ & $\begin{array}{l}6.0 \\
(9)\end{array}$ & $\begin{array}{l}6.48 \\
(16)\end{array}$ & $\begin{array}{l}6.46 \\
(18)\end{array}$ \\
\hline 13 & $\begin{array}{l}\text { Tax evasion is ethical if some of the } \\
\text { proceeds go to support a war that I } \\
\text { consider to be unjust. }\end{array}$ & $\begin{array}{l}4.45 \\
(8)\end{array}$ & $\begin{array}{l}4.9 \\
(9)\end{array}$ & $\begin{array}{l}3.6 \\
\text { (4) }\end{array}$ & $\begin{array}{l}4.0 \\
(2)\end{array}$ & $\begin{array}{l}5.03 \\
\text { (5) }\end{array}$ & $\begin{array}{l}5.04 \\
(6)\end{array}$ \\
\hline 14 & $\begin{array}{l}\text { Tax evasion is ethical if I can't afford } \\
\text { to pay. }\end{array}$ & $\begin{array}{l}4.16 \\
(3)\end{array}$ & $\begin{array}{l}4.5 \\
(5)\end{array}$ & $\begin{array}{l}3.9 \\
(5)\end{array}$ & $\begin{array}{l}4.8 \\
(7)\end{array}$ & $\begin{array}{l}5.63 \\
(9)\end{array}$ & $\begin{array}{l}5.06 \\
(7)\end{array}$ \\
\hline 15 & $\begin{array}{l}\text { Tax evasion is ethical even if it means } \\
\text { that if I pay less, others will have to pay } \\
\text { more. }\end{array}$ & $\begin{array}{l}5.03 \\
(16)\end{array}$ & $\begin{array}{l}6.1 \\
(13)\end{array}$ & $\begin{array}{l}5.1 \\
(11)\end{array}$ & $\begin{array}{l}6.0 \\
(9)\end{array}$ & $\begin{array}{l}6.28 \\
(12)\end{array}$ & $\begin{array}{l}6.37 \\
(17)\end{array}$ \\
\hline 16 & $\begin{array}{l}\text { Tax evasion would be ethical if I were a } \\
\text { Jew living in Nazi Germany in } 1935 .\end{array}$ & $\begin{array}{l}4.50 \\
(9)\end{array}$ & $\begin{array}{l}4.0 \\
(2)\end{array}$ & & & $\begin{array}{l}4.23 \\
(2)\end{array}$ & $\begin{array}{l}3.82 \\
(1)\end{array}$ \\
\hline 17 & $\begin{array}{l}\text { Tax evasion is ethical if the government } \\
\text { discriminates against me because of my } \\
\text { religion, race or ethnic background. }\end{array}$ & $\begin{array}{l}4.07 \\
\text { (2) }\end{array}$ & $\begin{array}{l}4.3 \\
\text { (3) }\end{array}$ & & & $\begin{array}{l}4.45 \\
(4)\end{array}$ & $\begin{array}{l}4.06 \\
\text { (2) }\end{array}$ \\
\hline 18 & $\begin{array}{l}\text { Tax evasion is ethical if the government } \\
\text { imprisons people for their political } \\
\text { opinions. }\end{array}$ & $\begin{array}{l}4.32 \\
(6)\end{array}$ & $\begin{array}{l}4.7 \\
(7)\end{array}$ & & & $\begin{array}{l}4.06 \\
(1)\end{array}$ & $\begin{array}{l}4.14 \\
\text { (3) }\end{array}$ \\
\hline
\end{tabular}

Note: Line 1: Scores 1= strongly agree; 7 = strongly disagree. Line 2 (in parentheses): Rank: 1 = strongest argument in favor of tax evasion; 18 [15 for Beijing and Hong Kong] = weakest argument in favor of tax evasion. 
Table 2

Highest Scores

\begin{tabular}{ll}
\hline & Frequency \\
\hline International Business Professors & 11 \\
Philosophy Professors & 4 \\
Guatemala & 2 \\
Romania & 1 \\
China & 0 \\
Hong Kong & 0 \\
\hline
\end{tabular}

Note: Tax evasion least acceptable

Table 3

Lowest Scores

\begin{tabular}{ll}
\hline & Frequency \\
\hline China & 11 \\
Romania & 3 \\
Philosophy Professors & 2 \\
International Business Professors & 1 \\
Hong Kong & 1 \\
Guatemala & 0 \\
\hline
\end{tabular}

Note: Tax evasion most acceptable 